\title{
Philosophical Arguments, Historical Contexts, and Theory of Education ${ }^{1}$
}

\author{
DANIEL TRÖHLER \\ University of Applied Sciences, Zurich and the Pestalozzianum Research Institute for the \\ History of Education
}

\begin{abstract}
This paper argues that many philosophical arguments within the education discourse are too little embedded in their own historical contexts. Starting out from the obvious fact that philosophers of education use sources from the past, the paper asks how we can deal with the arguments that these sources contain. The general attitude within philosophy of education, which views arguments as timeless, is being challenged by the insight that arguments always depend upon their own contexts. For this reason, citing past authors, heroes, or enemies without respecting the context says more about our interest at the present time than it does about the times of the authors examined. Conversely, the contextual approach helps us to avoid believing that 'timeless truths' are to be found in different texts of different ages. However, the present contribution in no way advocates a total relativization of statements. Quite the contrary; it claims that the contextual approach helps us to understand the traditions and contexts within which we ourselves, as researchers, are positioned. And this self-awareness is believed to be the proper starting position for theoretical statements about education.
\end{abstract}

Keywords: history of education, theory of education, linguistic context, empiry versus empiricism, Francis Bacon

\section{Outlining the Problem}

Seven years ago, in March 1997, the New York Review of Books published an essay with the interesting title, George Washington's False Teeth, which recently appeared also in book form. ${ }^{2}$ The author of the essay, historian Robert Darnton, is famous for his extensive research specializing in the second half of the $18^{\text {th }}$ century in Europe. Darnton writes that one of the most interesting sights on a tour of Mount Vernon is the display of the false teeth that belonged to the first President of the United States. When he looked at Washington's dentures, Darnton was reminded of a question that friends had often asked him, namely, if he, as a specialist in the field, would prefer to live in the $18^{\text {th }}$ century rather than in the $20^{\text {th }}$.

For a historian, Darnton says, this question is difficult to answer. But, if he lived in the $18^{\text {th }}$ century, he would first of all 'insist on being born well above the peasantry'. And second, he writes: 'No toothache, please. While reading thousands of letters from people in all walks of $18^{\text {th }}$-century life, I have often encountered toothaches. 
The pain cuts through the archaic language, and the writer looms up in your imagination, waiting in dread for an itinerant tooth-puller to arrive in town and, by a brief bout of torture, to put an end to the long weeks of agony' (Darnton, 1997, p. 38).

Darnton's account of visiting Mount Vernon is probably not invented, but was it really reason enough to write an essay about George Washington's false teeth and for the New York Review of Books to publish it? Of course not, for Darnton's actual aim is to foster discussion of a historiographical problem. That problem becomes manifest in the general opinion that the (late) $20^{\text {th }}$ century is more or less the hereditary descendant of the Enlightenment, and even more, of the Enlightenment. Darnton criticizes the inflated use of the term 'enlightenment' for almost all nonreactionary phenomena of the $18^{\text {th }}$ century, because blown up to such a size, it loses its meaning: 'The Enlightenment is beginning to be everything, and therefore nothing' (p. 34). Darnton is aiming for two things. First, he wants to 'reduce the Enlightenment to manageable proportions' (p. 34f.). There is, he says, no homogenous intellectual tradition that can be called the Enlightenment. He therefore proposes limiting the notion to the place where the idea was 'born' and to its exponents - to Paris and the circle of people who called themselves 'philosophes' and that represented a very different concept of modern thinking than, let's say, David Hume, Adam Smith, Edmund Burke, Winckelmann, Immanuel Kant, or Goethe. In other words, the Enlightenment is, according to Darnton, a historically and locally specific way of thinking. And the second thing Darnton wants to discuss is the problem that the inflated use of 'Enlightenment' leads to a facile identification of the ideas of the $18^{\text {th }}$ century with all modernity, as synonymous with much of what is subsumed under the name of Western civilization. Thus it can be easily made 'responsible for almost everything that causes discontent, especially in the camps of postmodernists and anti-Westernizers' (p. 35).

Darnton's two problems - the geographical homogenizing of the discussions in the $18^{\text {th }}$ century to the idea of the Enlightenment as well as the historic homogenizing by assuming the $20^{\text {th }}$ century to be the heir of the Enlightenment-both stem from an academic point of view that essentially pays too little attention to historical contexts. I would like to discuss the problems that can result when we in education pay too little attention to the historical contexts. I choose as an example a talk given by Richard Smith in Leuven, Belgium, last autumn at the annual meeting of an international research project called Philosophy and History of the Discipline of Education: Evaluation and Evolution of the Criteria for Educational Research. To be clear: In no way do I wish to offend the author or question the concerns that he has. I will also in no way judge the lucidity of his arguments or his hermeneutic competency. What I am interested in is the way in which 'arguments' are used to endorse these concerns - and in the question of how any modern theory of education has to deal with arguments that stem from the past.

\section{Arguments Without Context}

In his paper 'As if by Machinery: The levelling of educational research', Smith observes a tendency in current educational research that he labels 'levelling'. The 
search for the cause of this 'pernicious' tendency leads him back to 1620, when Francis Bacon published Novum Organum (The New Organon). In the preface to that work, Bacon pleaded for new methods, so that 'doing science' would be 'as if by machinery'. Now Richard Smith doesn't call into question the use of and the need for methods, but he raises suspicions concerning the 'democratic' implication of these ideas. Smith recapitulates that at the end of his first book, Bacon emphasizes that 'almost anyone can use the new method he advocates' (Smith, 2003 , p. 2). Smith then cites part of Bacon's $72^{\text {nd }}$ aphorism: 'But the course I propose for the discovery of sciences is such as leaves but little to the acuteness and strength of wits, but places all wits and understandings nearly on a level'.

To explain the problem that he has with Bacon, Smith then takes a text that was published 120 years later, David Hume's Treatise on Human Nature (1739/1740). The core citation is a passage in Book I, where Hume talks about 'rules' of research-which Smith identifies as the Baconian 'method'. Hume wrote: 'All the rules of this nature are very easy in their invention, but extremely difficult in their application; and even experimental philosophy, which seems the most natural and simple of any, requires the utmost stretch of human judgement' (Hume, 1739/1740/1961, p. 172). Hume 'puts the matter very aptly', Smith says. Why? Because applying whatever rules are stipulated still requires judgement, as Hume emphasized.

But Hume himself emphasizes the fact that the application requires 'judgement'. And, Smith says, 'there cannot be further rules for their application'; or if there are, there cannot be an endless series of such rules. ( ... ) And judgement is not a faculty that can be readily 'levelled', in Bacon's terms'. 'Judgement' is the core term Smith uses to 'prove' that Bacon's term of 'levelling' could be easily misunderstood. 'The qualities that make up judgement-flexibility, attentiveness, suitable experience and so on-are found more in some people than in others. They are found for instance in those who have a rich acquaintance with the subject-matter in hand, and in those prepared to attune themselves to the subject-matter rather than to treat it as one more field for the operation of pre-established skills and techniques' (Smith, 2003, p. 3).

In contrast though, nowadays 'almost any aspiring researcher' uses research methods regardless of 'his intellectual sophistication, quality of judgement and understanding of the subject being researched,' Smith complains, and he characterizes this phenomenon as 'continuation of the Baconian tradition'. Methodologically based research, irrespective of its specific value, causes problems when it 'stand [s] in for the cultivation of judgement and insight, and for acquaintance with the broader background of ideas and theory'; it even distracts from such cultivation and acquaintance and reduces the time available for them. Smith cites his Oxford colleague, the philosopher of education Richard Pring, who complains that 'much educational research espouses controversial philosophical positions without any recognition of the philosophical problems which they raise and which often have been well rehearsed by philosophers from Plato onwards' (Pring, 2000, pp. 5-6).

Philosophers of education, obviously, use past sources. With 'past' I am talking about the works of dead, Western, white men, like those cited earlier-Plato, 
Bacon, and Hume - and in other texts we find Kant, Hegel, and others too. What in the eye of an historian is so surprising is - and here we find the parallel to Darnton's complaints - that statements of former times seem to be used easily to build either a straight line to our present time-sometimes of decline or of advancement-or to compose a homogenous forum-some kind of an 'original position' (John Rawls) - where 'true' arguments are being exchanged. There are so many texts where you get the impression that, let's say, Plato, Locke, Rousseau, Kant, and Karl Marx are talking together at the same time in the same place-and we don't know whether to imagine Plato's academy, the Dutch exile of Locke, the village of Môtiers, the remoteness of Königsberg, or the British Library (where Marx worked). Would Plato think the same way in the $19^{\text {th }}$ century as he did almost 400 years before Christ? In other words: How can we imagine that a philosopher at the end of the Peloponnesian War living in a hectic and complex political situation is talking about the same thing when discussing 'truth' or 'idea' or 'justice' as a late $18^{\text {th }}$-century Pietist living in remote East Prussia? How do we know that a metaphor like the one 'as if by machinery' used by a British lawyer in 1620 refers to the same thing that it does in our postindustrial time? Sources are only sources when they represent in some way their own historic context, and not our concerns or problems.

\section{Arguments in Context}

I think the idea of 'talking together' is a fruitful image if we restrict it to contemporary discussions. Let me demonstrate this in detail by means of Francis Bacon. Novum Organum, published in 1620, is the first and only printed part of his planned work Instauratio Magna (The Great Instauration). Bacon was not a philosopher, but a broadly educated lawyer and politician. Due to political intrigues in that year of 1620, Bacon was forced to resign from government office, and he devoted himself to his philosophic work. But he died just six years later, having published only the first part of his work. The Novum Organum has a famous frontispiece, about which the book says little. But in The Advancement of Learning, a book published 15 years previously and the only work Bacon wrote originally in English, Bacon describes the scene depicted in this frontispiece in a dedication to the new king of England, Jacob I, the Stuart successor of Elizabeth who had died in $1603 .^{3}$

Bacon writes in 1605:

'... there is not any more worthy [act] than the further endowment of the world with sound and fruitful knowledge. For why should a few received authors stand up like Hercules' columns, beyond which there should be no sailing or discovering, since we have so bright and benign a star as your Majesty to conduct and prosper us?'. (Bacon, 1605/1973, p. 61)

Obviously Bacon is dissatisfied with the limiting of knowledge to 'a few received authors'. If Richard Smith is tracing a line from dull, contemporary educational research back to Bacon by blaming the 'levelling' of science that put aside any intelligent judgement, Bacon has to be defended. Bacon says: 
'For it generally happens that men make their trials carelessly, and as it were in play; slightly varying experiments already known, and, if the thing does not answer, growing weary and abandoning the attempt. And even if they apply themselves to experiments more seriously and earnestly and laboriously, still they spend their labour in working out some one experiment, as Gilbert with the magnet, and the chemists with gold; a course of proceeding not less unskilful in the design than small in the attempt. For no one successfully investigates the nature of a thing in the thing itself; the inquiry must be enlarged so as to become more general'. (Bacon, 1620/1997, \LXX)

And if Richard Smith seems to complain that Bacon had an attitude that might be labelled 'democratic', we have to ask why he did and what its purpose was in his time. Cambridge historian Richard Tuck has taught us that the roots of this thinking lie in the so-called Venetian Tacitism or Tacitist Humanism (Tuck, 1993, pp. 105ff.), which was popular in Bacon's times and almost timelessly deposited in Shakespeare's Tragedy of King Richard the Second, first performed in 1595. Virtue is the key word of this political ideology — an ideology that later was realized somewhat unfortunately in the English Commonwealth in the mid- $17^{\text {th }}$ century.

The political-scientific-human ideal of Bacon and this Venetian republican tradition of Tacitus refer to his emphasis on activity for the benefit of the people. There is a strong ethical implication in Bacon's program of fostering the modern way of gaining knowledge. Now, Bacon's ideas did not come to him deus ex machina. Bacon lived in a time that is considered to be the beginning of capitalistic society. Here are some highlights of Bacon's times and context:

- In 1570 Thomas Gresham erected the London stock market;

- In 1586 Sir Walter Raleigh attempted to found the colony of Virginia;

- In 1588 the Great Armada was beaten and thus Britain won naval supremacy;

- In 1600 the East India Company was established.

It is no coincidence that in the frontispiece I mentioned above, Bacon showed a ship sailing to new worlds, needing new and better knowledge for safer sailing and coming home with new knowledge, knowledge that neither Aristotelianism nor scepticism could ever imagine. What Bacon tried to do was just to be active and curious, to separate miracles from knowledge, and to invent a method with which knowledge becomes knowledge. We should not forget that only five years before Bacon wrote his Advancement of Learning in 1605, the Roman Catholic Church murdered Giordano Bruno also because he believed in the heliocentric system.

One might argue that this is correct, but insist that Bacon was the first man of the time that we call the 'scientific revolution' and, therefore, tracing this back to Bacon appears to be reasonable. One might say that to define a context only using some information about trade and commerce and republican ideals is not enough to change the picture. However, Bacon was not the first experimenter at all, as we will see, and even worse, there was no scientific revolution at all, as Steven Shapin 
has shown in his book The Scientific Revolution, which begins: 'There was no such thing as the Scientific Revolution and this is a book about it' (Shapin, 1996, p. 1). On a trip to Paris in 1576, Bacon had already visited Bernard Palissy (1510-1590), a famous potter who was advocating the importance of experiments, collection of specimens, and teaching by means of practical demonstrations, and he must have known Giambattista Della Portas' (1535-1615) Magia Naturalis (1558), in which the author examines the natural world claiming it can be manipulated by the natural philosopher through theoretical and practical experiments (see Clubb, 1965). Besides Bacon, in England William Gilbert (1544-1603) ${ }^{4}$ and William Harvey (1578-1657) ${ }^{5}$ belonged to the experimentalists (Pumfrey, 2002; Cunningham, 2002), although Bacon felt that he himself was more sophisticated than the empiricist Gilbert. Bacon was in lively public discussion with his forerunners of empirical research in the $16^{\text {th }}$ century. ${ }^{6}$

I in no way want to construe a different-that is, earlier-starting point of modern science than Bacon. There was, namely, no identifiable starting point, and it certainly did not start with one single person. I think Steven Shapin is right when he argues that 'science is a historically situated and social activity and it is to be understood in relation to the contexts in which it occurs'. It is 'a collectively practiced, historically embedded phenomenon, inviting readers to see whether the account is plausible, coherent, and interesting'. And I agree with Shapin that the old debate about the priority of intellectual factors versus social factors is fruitless. If science is to be understood as historically situated and in its collective aspect, then this understanding has to encompass all aspects of science, its ideas, and its practices, no less than its institutional forms and social uses (Shapin, 1996, p. 9).

If this understanding of history is correct and accepted by the scientific community, we have to abandon several ideas about the past that we have held dear. We will find hardly any epochs like the Enlightenment anymore, no beginnings or endings of epochs; we will recognize that there are heroes or classics of the several disciplines, but that they are construed as classics later on. And historian Quentin Skinner said, while arguing in favour of research of contexts rather than of 'pure' ideas, that a historiographical concept such as this 'leaves the traditional figure of the author in extremely poor health' (Skinner, 1988b, p. 276). The leave-taking of those ideas of the past opens up the field of historical research. What we will find are different settings of discussions, problem solving, debates, or discourses, defining the problems as problems and trying to find answers-in their time and for their time.

\section{Empiry versus Empiricism}

Of course, historians can talk this way. They can limit their research to deconstructing historical constructions, they can relativize 'big names', dissolve arguments in contexts, and give a shrug when we ask-what is it all about? What help is this? As educationalists we find ourselves in quite a different position from historians, because - at the end-we need to be able to formulate normative statements. Education is a social practice that can be done better or worse, and our job 
is to find relevant arguments for the better and the worse. But if 'pure' arguments of our historic heroes or enemies may not be cited anymore, and history furthermore just reconstructs contexts rather than the dignity of single arguments, the theorist does not know where to take arguments from anymore. Or, in other words and referring to Richard Smith: If everything seems to be empirical, where is the faculty of judgement? Hence: don't the arguments that I make here reinforce Richard Smith's position?

I don't think so. I would like to draw an important distinction between empiry and empiricism. For to abandon the idea of the existence of pure arguments of any philosopher does not mean at all that we have to be thrown into blindly counting sacks of pepper in the harbours of India or registering tobacco bales in Virginia. I agree with Richard Smith that much modern research in education is dull, not because of Bacon, but because of its empiricist setting. The problem of empiricism is not the lack of eternal ideas, but the frequent lack of reflective thinking on the basic question. If the questions, as the basis of research, are in any case inescapably historic, meaning empirical, we find that empiricist studies often are not empirical enough. Or, in other words: empiricism often lacks empiry as much as strictly philosophical approaches do, too.

The question we are really discussing is how to handle the incompatible alternatives of dogmatism and scepticism, or of philosophy without empirical context and empiricism without reflection. That was the problem Bacon was facing, and many others throughout history, too. I think that even pragmatism developed out of such a problem. The historic differences are indicated by the way in which this problem was understood or interpreted, how solutions were developed, how they were influenced by other contemporary solutions or by their interpretations of past authors, and how they were able to convince their contemporaries. So what a historical study has to do, in other words, is to reconstruct how the diverse discourses developed, which of the discourses gained dominance-and why and for how long. And this character of research is empirical in the sense that we try to see whether or not a certain mode of thinking-or 'discourse' if you want to be both popular and somewhat fuzzy - has predominated or not.

History in this sense is at the same time philosophical and empirical, because it wants to understand beliefs and commitments that grew or disappeared against the background of specific social and intellectual developments and conditions. Inevitably, this forces research to include examination of not very readily accessible pamphlets, clandestine literature, manuscripts, or simply 'forgotten' books and magazines. Historical work thereby takes on an archaeological character. 'This historian is in considerable measure an archaeologist; he is engaged in uncovering the presence of various language contexts in which discourse has from time to time been conducted' (Pocock, 1987, p. 23). The claim that philosophical arguments can only be understood by reconstructing the linguistic context is not the same as to be un-philosophical. It is just another understanding of philosophy than the traditional, a post-idealist philosophy influenced by the so-called 'linguistic turn.' Quentin Skinner referred explicitly to John G. A. Pocock when defining the work of historians as the study, primarily, of the "languages" of discourses, and only 
secondarily of the relationship between individual contributions to such languages' (p. 276f.). ${ }^{7}$ The langue is the ideological context, and it has 'the character of paradigms' (p. 21).

To go back to the example of Bacon: The Royal Academy of the $17^{\text {th }}$ century proves that the critique of dogmatic idealism was widely received (Osterwalder, 1999). They construed their hero, Francis Bacon, as shown in the frontispiece ${ }^{8}$ of Thomas Sprats' 1667 History of the Royal Society. A bust of the Restoration king, Charles II, rests on a column that is flanked to the left by the President of the Royal Society and to the right by Francis Bacon, who had died forty years before. Above them we see the maxim Nullius in verba-no truth lies in words, but only in things. Accordingly, a small library symbolizing 'ancient philosophy' is shown almost hidden in the shadows, while Bacon points to a set of illuminated instruments used in experiments and modern mechanics. Standing fully illuminated by the sun is the instrument that was responsible for the enormous success of the Royal Academy, Robert Boyle's air pump.

But whether or not the Royal Academy is the true heir of Bacon and his time is another question - the members believed that they were, and they needed a past hero to legitimize the Academy itself. ${ }^{9}$ Looking historically at history means not forgetting that, for example, Thomas Hobbes could be called an heir as well, but a different one, and that England had other discourses that we can identify todayJohn Milton's religious civic humanism and the so-called Cambridge Platonists like Henry Moore, Benjamin Whichcote, or Ralph Cudworth. We must not forget that $17^{\text {th }}$-century Great Britain was a time of deep political, social, economic, and religious crisis - it is no coincidence that Hobbes was writing Leviathan in his exile in France, no coincidence that hundreds of so-called Puritans moved to the New World when the idea of the commonwealth was corrupted by the egomaniacal and autocratic Cromwell, no coincidence that at the end of the century a second revolution occurred.

\section{Arguments, Contexts, and Theory of Education}

Hence, citing past authors, heroes, or enemies without respecting the context says more about our interest at the present time than it does about the times of the cited author. Conversely, the contextual approach helps us to avoid believing in 'timeless truths' to be found in different texts. And moreover, it helps us to understand the traditions within which we ourselves, as researchers, are positioned-knowledge that allows us in the end to 'choose among', or rather balance, the different langues (Pocock) or ideologies (Skinner). This is not meant to be psychological, but ideological. 'To discover', Skinner says, 'from the history of thought that there are in fact no such timeless concepts, but only the various different concepts which have gone with various different societies, is to discover a general truth not merely about the past but about ourselves as well' (Skinner, 1988a, p. 67). To learn from the past means separating necessity from contingency, which is 'the key to self-awareness itself' (op. cit.). Probably there are eternal problems, but they show up always in different forms, and we are compelled to 
know the alternative possibilities that have historically grown into our present time-whether they are dominant or not. If then we resist belief in metaphysical cues when making choices, all we can do is discuss the advantages and disadvantages of the possibilities that we are aware of publicly-best of all internationally, without claiming that one solution is the best forever. And the informed public discussion of educated citizens knowing alternatives represents the ideal of the political system in the Western World today, e.g. democracy.

Therefore, the general truth is that there is no general truth, and that history changes the problems, the paroles, and the langues, as they themselves change history. For language is not just a reflection of reality, but according to the linguistic turn, it construes reality. History changes the circumstances and provokes new problems, new paroles, and they change the langues. New realities mean new constraints and new challenges that need to be mastered or at least answered. But to give a 'proper' answer is not a question of eternal truth, but of the empirical context-the best advice in the $17^{\text {th }}$ century may well differ from the best advice for today, even if the problem in both cases is the 'same', such as, for example, political stability. Many of the problems remain in a certain way the same, but the answers do not, because the specific questions arising out of the problem are different. Justice is politically the uppermost good, in Plato's time as in ours, but Plato's answers do not help in an industrialized and democratic society. If we want to formulate it paradoxically: Everything is the same, and everything has changed. The question asked of Robert Darnton as to whether he would prefer to live in the $18^{\text {th }}$ century is legitimate for friends but somehow improper to historians. Toothaches in the $18^{\text {th }}$ century were as dreadful as they are today but also worse, because we have modern dentistry, and we can trust in fast professional pain relief.

\section{Notes}

1. This paper was presented as a lecture at the main conference of the EERA in Crete, 2225 September 2004. The core ideas of this paper were first presented in a guest lecture at Rice University in Houston, Texas, 13 March 2004.

2. Robert Darnton (2003) George Washington's Teeth. An unconventional guide to the Eighteenth Century (New York, W. W. Norton).

3. Elizabeth was the daughter of Henry VIII, the first Tudor King, famous for his eight wives and responsible for the separation of the 'Anglicana Ecclesia' from the Roman Catholic Church in 1534.

4. In his major work, De Magnete (1600), Gilbert boasted rightly that the method evident in his book was experimental (see Pumfrey, 2002, p. 6).

5. William Harvey is the celebrated discoverer of the circulation of the blood. 'All of our modern physiological understanding is based on this discovery' (Cunningham, 2002, p. 21).

6. 'The race of chemists, again out of a few experiments of the furnace, have built up a fantastic philosophy, framed with reference to a few things; and Gilbert also, after he had employed himself most laboriously in the study and observation of the loadstone, proceeded at once to construct an entire system in accordance with his favorite subject' (Bacon, 1620, \LIV).

7. History, Pocock says, is to be understood as interaction between langue and parole (Pocock, 1987, p. 19f.). In this view, history is a transmission of 'acts of speech, whether 
oral, scribal or typographical'. But the acts of speech are determined by the contexts 'in which these acts were performed'. The paroles of any historical actor always depended on a specific langue: 'For anything to be said or written or printed, there must be a language to say it in; the language determines what can be said in it, but is capable of being modified by what is said in it; there is a history formed by the interactions of parole and langue' (p. 20).

8. The frontispiece was printed only in luxury copies.

9. In fact, that was the purpose of the Sprat's History, too.

\section{References}

Bacon, F. [1605] (1973) The Advancement of Learning (London, J.M. Dent \& Sons).

Bacon, F. [1620] (1997) The Great Instauration and the Novum Organum (Whitefish, MT, Kessinger Publishing).

Clubb, L. G. (1965) Giambattista Della Porta, Dramatist. (Princeton, NJ, Princeton University Press).

Cunningham, A. (2002) William Harvey, in: P. Harman \& S. Mitton (eds), Cambridge Scientific Minds (Cambridge, Cambridge University Press).

Darnton, R. (1997) George Washington's False Teeth, New York Review of Books, 44:5.

Darnton, R. (2003) George Washington's Teeth. An unconventional guide to the eighteenth century (New York, W.W. Norton).

Hume, D. [1739/1740] (1962) A Treatise of Human Nature (London, Dent \& Sons).

Osterwalder, F. (1999) Pädagogik im Umfeld moderner Naturwissenschaft im 17. Jahrhundert, in: J. Oelkers \& D. Tröhler (eds), Die Leidenschaft der Aufklärung. Studien über Zusammenhänge von bürgerlicher Gesellschaft und Bildung (Weinheim, Beltz).

Pocock, J. G. A. (1987) The Concept of a Language and the Métier d'Historien: Some considerations on practice, in: A. Pagden (ed.), The Languages of Political Theory in Early-Modern Europe (Cambridge, Cambridge University Press).

Pring, R. (2000) Philosophy of Educational Research (London, Continuum).

Pumfrey, S. (2002) William Gilbert, in: P. Harman \& S. Mitton (eds), Cambridge Scientific Minds (Cambridge, Cambridge University Press).

Rawls, J. (1971) A Theory of Fustice (Cambridge, MA, Harvard University Press).

Shapin, S. (1996) The Scientific Revolution (Chicago, IL, University of Chicago Press).

Skinner, Q. (1988a) Meaning and Understanding in the History of Ideas, in: J. Tully (ed.), Meaning and Context: Quentin Skinner and his critics (Princeton, NJ, Princeton University Press).

Skinner, Q. (1988b) A Reply to my Critics, in: J. Tully (ed.), Meaning and Context: Quentin Skinner and his critics (Princeton, NJ, Princeton University Press).

Smith, R. (2003) As if by Machinery: The levelling of educational research. Talk at the Vlaanderen Fund for Scientific Research: Philosophy and History of the Discipline of Education-Evaluation and Evolution of the Criteria for Educational Research (Leuven, Belgium) [paper removed from the Web]. Published in D. Bridges and R. Smith (eds), Philosophy and Educational Research, Special Issue of Fournal of Philosophy of Education 40:2, 2006, pp. 157-168.

Sprat, T. (1667) The History of the Royal-Society of London: For the improving of natural knowledge (London, Printed by T.R. for J. Martyn at the Bell without Temple-bar, and J. Allestry at the Rose and Crown in Duck-lane, printers to the Royal Society).

Tuck, R. (1993) Philosophy and Government 1572-1651 (Cambridge, Cambridge University Press). 